\title{
Vision, leadership, and scholarship
}

\author{
David H. Adams, MD
}

\author{
From the Department of Cardiovascular Surgery, Mount Sinai Health System, New York, NY. \\ Disclosures: Author has nothing to disclose with regard to commercial support. \\ Read at the 99th Annual Meeting of The American Association for Thoracic Surgery, Toronto, Ontario, \\ Canada, May 4-7, 2019. \\ View the presentation online: https://www.mitralvalverepair.org/profile/david-h-adams. \\ Received for publication Oct 11, 2019; revisions received Oct 11, 2019; accepted for publication Oct 11, 2019 \\ Address for reprints: David H. Adams, MD, Department of Cardiovascular Surgery, Mount Sinai Health System, \\ 1190 Fifth Ave, New York, NY 10029 (E-mail: david.adams@mountsinai.org). \\ J Thorac Cardiovasc Surg 2019;158:1607-13 \\ $0022-5223 / \$ 36.00$ \\ Copyright (C) 2019 Published by Elsevier Inc. on behalf of The American Association for Thoracic Surgery \\ https://doi.org/10.1016/j.jtcvs.2019.10.030
}

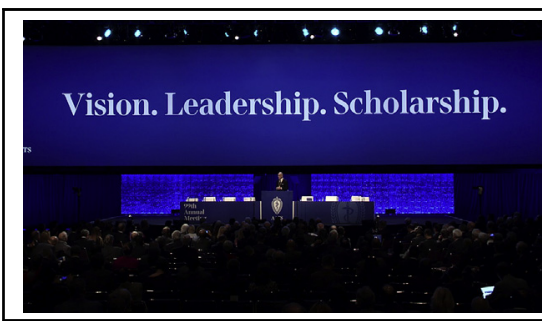

Dr David Adams delivering his Presidential Address on May 6, 2019.

Central Message

Progress is never inevitable. Progress is fueled by dissatisfaction, impatience, and vision.
INTRODUCTION OF DAVID H. ADAMS, MD, 99TH PRESIDENT OF THE AMERICAN ASSOCIATION FOR THORACIC SURGERY

\section{Vaughn A. Starnes, MD:}

Good morning. I'm Vaughn Starnes, and it's my great honor to introduce Dr David Adams, our 99th President. Even in a field that draws the best and brightest, David is exceptional. He is a remarkable surgeon, a caring and dedicated teacher, and a true innovator. He has challenged all of us to push forward in what is often a conservative specialty. And his vision for where we need to go, and his drive to get us there, are invigorating.

The first thing you should know about David is that he is the result of a true love story. His parents, Jean Pugh and Morgan Adams Jr, met as freshmen at Duke University, and dated throughout college. After graduation, Morgan entered active duty in the Navy. No matter where he was, in ports of call around the world, he wrote Jean a letter every day, sometimes twice a day, for 2 years. Here's just one example of their profound connection: "There isn't very much news. I love you even more than I did when I wrote you this morning." They married shortly after he returned from overseas, then started their family when Morgan was still in medical school, at the University of Louisville. David's older brother Morgan arrived first, followed by David and his twin brother, Bill, in 1957 (Figure 1).

David grew up in Greensboro, North Carolina. In many ways, his was a typical Southern childhood of the era. Lots of church, lots of chores, and lots of sports. Here he is as a young point guard; as you can see, this is a young man who already has Duke University on his mind. David studied at Duke for 8 years, staying on for medical school. There, Dr David Sabiston identified him as an exceptional talent, and cultivated his interest in heart surgery. I'd like to emphasize that this early mentorship shaped David in 2 ways: First, it guided him into thoracic surgery. Second, if you work with David and see him teach, you'll note that he sees early mentorship as an imperative, and passes that gift on to other young surgeons, himself.

Following medical school, David completed his residency in general and cardiothoracic surgery at Brigham and Women's Hospital in Boston. Here is an early photograph; you can see both David and his chief resident, Dr David Sugarbaker. In addition, he spent 2 years doing a research fellowship under Dr Morris Karnovsky, in the Department of Pathology at Harvard Medical School. After his pathology research fellowship, David went off to London to train with Sir Magdi Yacoub, in transplantation. And in 1992, David joined the cardiac surgery staff at the Brigham, rising to become Associate Chief, under Dr Lawrence Cohn. During that time, he also established a primate xenotransplant lab at the Brigham, all while maintaining a busy clinical practice.

In 2002, he was recruited to succeed Dr Randall Griepp as the Marie-Josée and Henry R. Kravis Professor and Chairman of Cardiovascular Surgery at Mount Sinai, and has since become the Cardiac Surgeon-in-Chief of the Mount Sinai Health System.

David's interest in mitral surgery grew out of his work caring for patients with advanced heart failure. This in turn led to a long and close collaboration with Dr Alain Carpentier, in Paris. Over an 8-year period, they co-authored (along with Dr Farzan Filsoufi), Carpentier's Reconstructive Valve Surgery-which has since become the benchmark textbook in the field. Obviously, David believes in scholarship and innovation. He has published more than 350 peer-reviewed articles, and given more than 500 invited lectures. He is an honorary professor at universities around the world and last year received the 


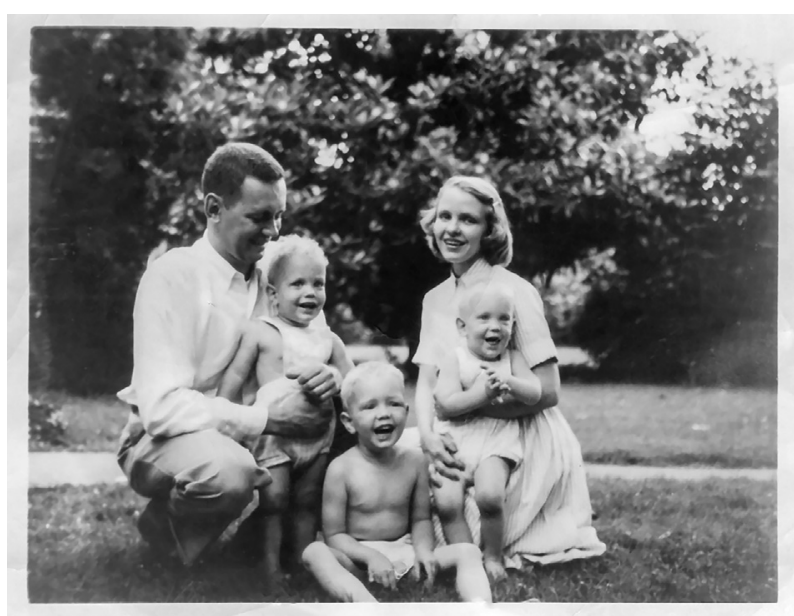

FIGURE 1. A young David Adams (second from left) is held by his father, Morgan, alongside his older brother Morgan (center), and his twin brother Bill, who is held by his mother Jean.

Bakulov Award in Moscow. In addition to his work in mitral valve repair, David serves as the national co-principal investigator on multiple Food and Drug Administration trials that are changing the practice of valve intervention. And if you have ever used a mitral or tricuspid ring, odds are you used one that David either invented or co-invented-because his are now among the most widely used in the world.

I wouldn't be introducing David as our next President if he were not a gifted surgeon. With his mitral team at Mount Sinai, he performs more than 400 valve operations per year and is consistently recognized in the New York State Registry Report for superior outcomes. For many, that would be enough. But, again, David is a dedicated teacher and mentor, one who is committed to sharing his knowledge

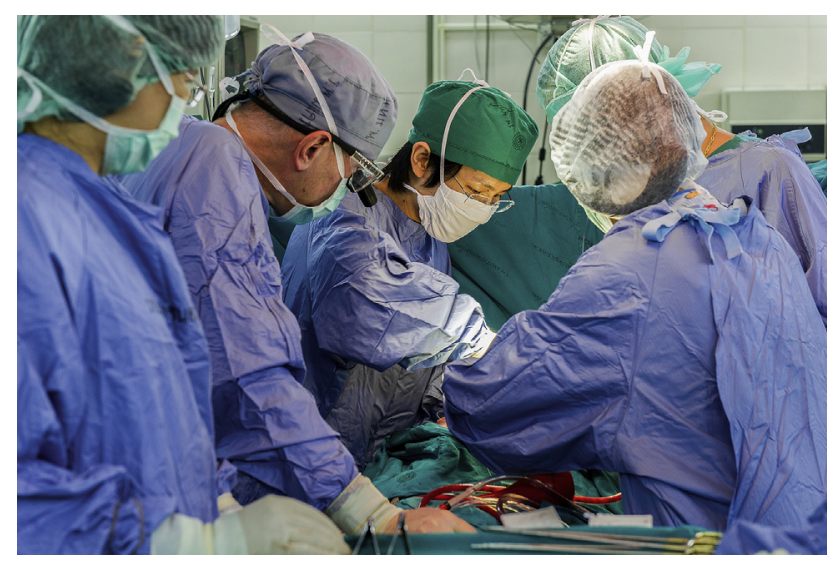

FIGURE 2. Dr Adams operates alongside Dr Tepsuwan in Chiang Mai, Thailand, where they are collaborating to establish a Center of Excellence in Mitral Surgery. It exemplifies Dr Adams's commitment to mentorship around the world. with other surgeons and advancing the quality of cardiac surgery everywhere. To that end, he founded the AATS Mitral Conclave, which last week drew nearly 1500 participants from 67 countries, and is now the preeminent mitral conference in the world.

In addition to bringing people together, David takes his invaluable knowledge out into the world. He has operated on more than 300 patients in 10 countries outside the United States, always teaming up with local surgeons to help them develop and hone their own abilities. He has made more than 20 trips to China alone, most recently helping surgeons there perfect mitral techniques. Through such travel and mentorship, he has spread life-saving skills around the globe. As a part of this international commitment, David helped establish a mitral center of excellence at Chiang Mai University, in Thailand. I know he considers this to be one of his greatest achievements (Figure 2).

Titles, patents, and numbers, however, don't tell the whole story. And they certainly don't tell the most important story of being a doctor. This is a thank-you note to David from the parents of a 16-year-old girl who needed emergency surgery on Christmas Eve. "Dear Dr Adams, When the unthinkable happens to your family, you can only hope that the help that arrives is a fraction of what we experienced with you. You have been generous, kind, and exceptionally wonderful with Laura's surgery. Thank you, thank you. Your team is amazing."

There are many scholars and innovators in this world. That note is to someone who never forgot the most important part of being a doctor: compassion. And that caring sprit infuses David's whole life. Having worked closely with David, I know him to be an extraordinary leader, a heartfelt champion of our specialty, a good friend, and a master surgeon. So please join me now in welcoming our 99th President, Dr David Adams.

\section{PRESIDENTIAL ADDRESS}

\section{David H. Adams, MD:}

Thank you so much, Vaughn, for that incredibly warm introduction. Honestly, I'm humbled. You are a true friend, and a great leader in this organization.

It's also an indescribable privilege to be here today with all of you.

In 1960, when I was 2 years old, my dad was completing his ophthalmology residency at the University of Iowa, when he was diagnosed with acute blast leukemia. Back then, that was an incurable disease, and 6 months later, he died at the local Veteran's hospital. My mom, suddenly a widow at 29, moved me and my 2 brothers-Morgan and Bill—back to Greensboro, to be near her parents. Because I was so young, I didn't realize the challenges she faced. She sewed her own clothes. She bought ours twice a year from the Sears \& Roebuck catalog. And when we took a vacation, we stayed with relatives, or went to a church 
camp. My mom was the strongest person I've ever known. As hard as it must have been to lose the one and only love of her life, I never once heard her complain about her fate. She believed God had a plan, and she just focused on raising her 3 boys. Despite our modest means, we never wanted for anything - she filled us with confidence, taught us the importance of kindness, generosity, and integrity, and instilled in us a deep sense of purpose that still inspires me today.

My grandfather, Harold Pugh, was also a big part of my life growing up. He was known around our house as "The Colonel." He took us to the barber twice a month, church twice a week, and-because modesty was his virtue-he often wore paperclips for cufflinks. He believed that hard work built character and kept boys out of trouble, so as soon as we were old enough to push a lawn mower, we did. Every spring and summer, every Friday afternoon and all-day Saturday, my brothers and I mowed yards until we ran out of daylight. And no matter how hot the weather or how long the day, he insisted we do the job right, every time. That same work ethic paid off in high school. But to my great frustration, I finished second in my class. I wasn't valedictorian, because I struggled in 2 classes that my mom insisted I take: typing and chorus. I'm still not very good at either one.

When I got to Duke as a freshman, I'd already decided I would follow in my father's footsteps and become a doctor. Unfortunately, things got off to a pretty rough start. On my first midterms, I got two B-minuses, one C, and a D. A few days later, my academic counselor called me into her office and sat me down. She said: "David, we need a new plan, because you are never getting into medical school." I've never liked being told I can't do something-it only makes me want to work harder. And I did.

The summer before my senior year, I volunteered as a scrub tech at Duke University Hospital. One day on my way to lunch, I saw several doctors going into the amphitheater that overlooked one of the operating rooms. Curious, I followed them in, and saw a surgeon-surrounded by a large team-performing a coronary bypass operation. That surgeon was Dr David Sabiston, who would go on to become the 65th President of this Association. Everyone in the operating room simply called him "The Man." Seeing him work was an epiphany to me. Later that day, I called my mom from a hospital pay-phone booth and told her: "I'm going to be a heart surgeon."

When I got into medical school, Dr Sabiston was more than a professor to me-he became my first mentor. He saw something in me. He nurtured my interest in academic cardiac surgery, and he really pushed me. In this spirit, he loved the quote by the medical pioneer, Sir William Osler, who said: "hard work is the great equalizer." Those words really resonated, in part because of the lessons my grandfather had taught me, and also because of my early academic struggles as a freshman. But when I started my surgical residency, I learned that hard work alone was not enough. One of my first rotations as a surgical intern at the Brigham was on Plastic Surgery. It was run at the time by Dr Joseph Murray, who went on to win the Nobel Prize for his pioneering work in transplantation.

One Saturday on rounds, we crossed the bridge to Boston Children's, where we saw a young girl whose hand was inflamed from an IV infiltration. I listened carefully as Dr Murray told the medical chief resident what to do in terms of elevation and dressings. Later that afternoon, after Dr Murray had gone home for the day, I was back at the Brigham dictating charts, when I got a call from the same chief resident; another child had suffered a similar problem, and he was going to provide the same treatment. I asked him: "Should I come over?" He told me "No need. Just add her to Dr Murray's patient list for rounds tomorrow." The next morning, when I told Dr Murray, he asked me to describe what I had seen. Reluctantly, I told him that I hadn't actually gone to see the patient. A few days later, Dr Murray led me through the debridement of the necrotic skin on her hand, and then called me into his office and shut the door. I've never forgotten what he told me. He said: "David, regardless of your position on a team, if you're consulted on a case, you have to see the patient yourself. You make an assessment. You help define the course of treatment. Be a doctor!"

Another great mentor was Dr Lawrence Cohn, our 79th President, who was my Chief at the Brigham for more than a decade (Figure 3). I wish he were here today... he would have been so proud. Dr Cohn always challenged those of us around him to think on our feet. As a master of positive confrontation, he taught us 2 key lessons: be prepared, and be decisive.

Dr Aldo Castañeda, our 74th President, was another key mentor. After completing my training in adult cardiothoracic surgery at the Brigham, I began a 6-month rotation at Boston Children's in Dr Castañeda's department. After scrubbing with him for a week, he pulled me aside and said: "So I hear you're a real hotshot, David, and that Dr Cohn has already offered you a job-maybe it's time you actually learn how to tie a knot." He pointed out that I wasn't consistent when tying knots, and that I didn't seem to have any real plan. He then took out a silk and showed me a subtle motion that he always repeated, and went on to explain the importance of purpose, finger position, tension, and rhythm. He told me to practice that motion on every single knot I tied on his service... and I did, thousands of times. That turned out to be one of the best lessons of my career, and since then, I've always given the "Castañeda knot class" to every one of my own trainees. Many years later, when Dr Castañeda 


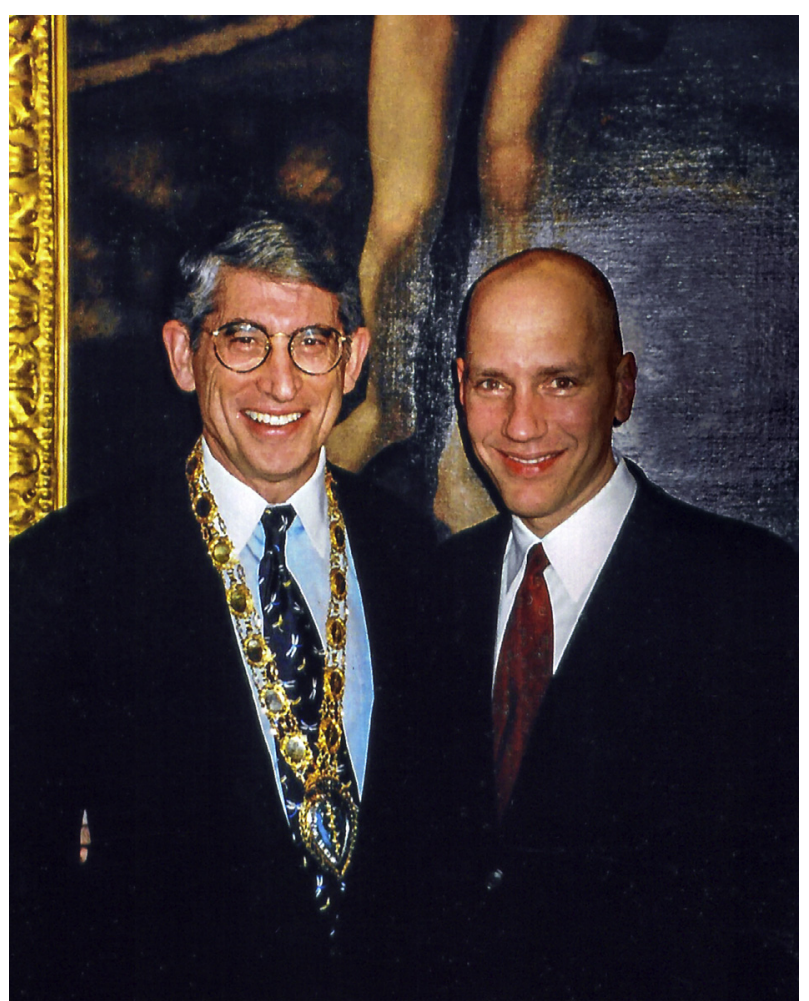

FIGURE 3. Dr Adams with Dr Cohn at Dr Cohn's AATS presidential reception in 1999.

himself needed valve surgery, he called me to ask if I would be his heart surgeon. His trust in me was one of the greatest honors of my career. I promised him perfect knots (Figure 4).

Of course, this story isn't really about knots... it's about how teaching discipline perpetuates excellence, and how we pass that on from generation to generation. That lesson was

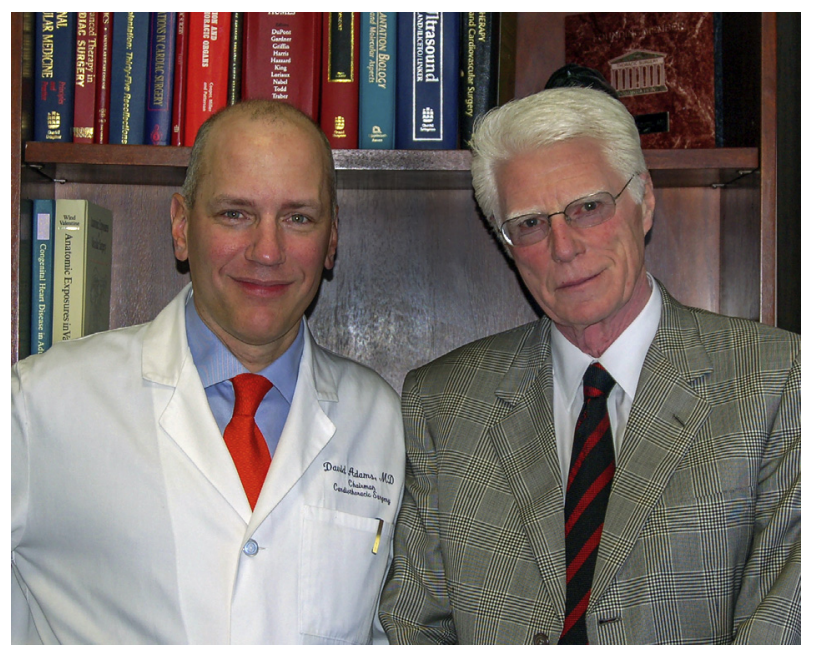

FIGURE 4. Dr Adams with Dr Castañeda a few months after his successful valve repair. reinforced during my fellowship in London, where Sir Magdi Yacoub taught me the difference between being a fast surgeon and being an efficient surgeon. Magdi was a master of disciplined efficiency.

As we get older, the line blurs between mentor and friend. Dr David Sugarbaker, our 94th President, was a larger-thanlife influence and close friend of mine from my days as an intern until his passing last year. David taught me, and a generation of surgeons, the power of focused attention. Dr Friedrich Mohr trusted me to perform live surgery at a very early stage in my mitral career, which gave me a great deal of confidence. He also joined Dr Wayne Isom and Dr Valentin Fuster in convincing me to leave the Brigham and succeed Dr Randall Griepp at Mount Sinai, in New York. Randy was a loyal friend and mentor during my early tenure as a young Chairman, and for the past 18 years, I've had the great privilege of working closely with Valentin. I'll be forever grateful for his partnership and belief in me. Dr Pedro del Nido, our 95th President, has offered me continuous friendship, and the wisest counsel, for the past 25 years. And our 85th President, Dr Tirone David-a role model in my surgical youth-is now another of my closest friends. We call each other often to talk about the American Association for Thoracic Surgery (AATS), and the lessons we learned from our toughest cases.

Lastly, you've heard about the influence that Dr Alain Carpentier had on my career in mitral valve reconstruction

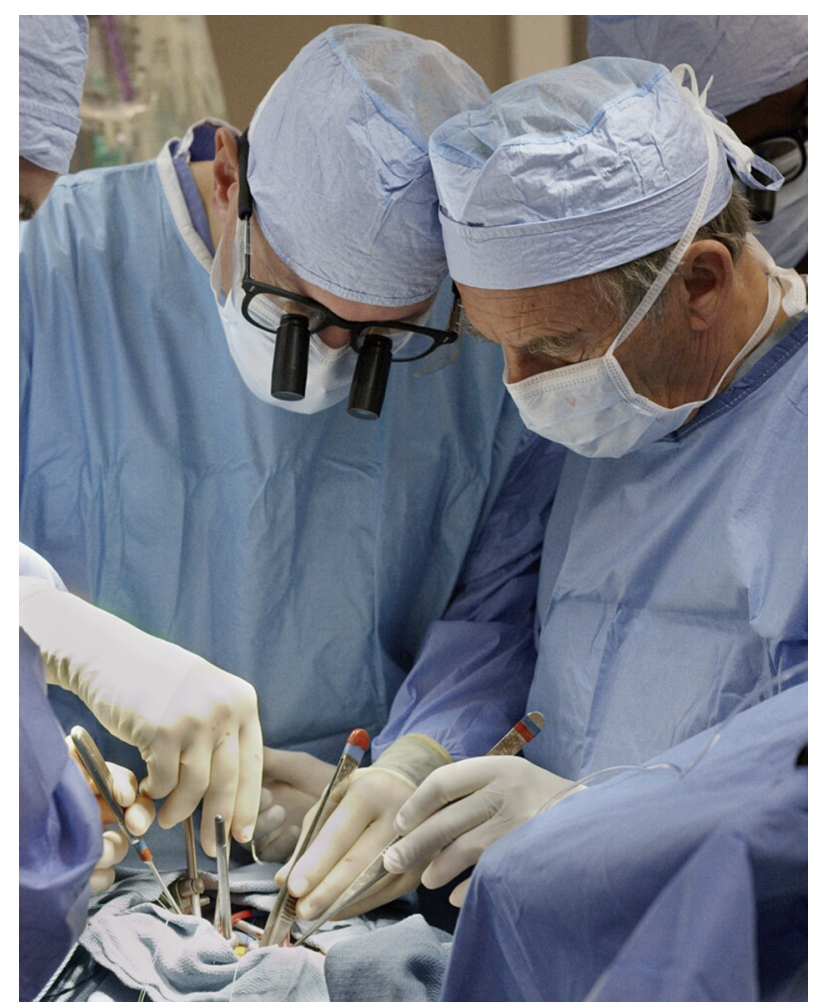

FIGURE 5. Dr Adams and Dr Carpentier operating together in New York. 
(Figure 5). But actually, the biggest lesson I learned from him wasn't about the mitral valve at all.

As many of you know, for over 2 decades, Dr Carpentier ran Club Mitrale, which was the most famous valve course of all. Surgeons from around the world came to watch him perform live operations at Hospital Broussais, in Paris. When I was the chief resident in cardiac surgery, Dr Carpentier was our Visiting Professor, and he gave me an open invitation to attend. A few years later, as a young staff surgeon, I took him up on his offer. On the last day of the course, his final procedure was a complex rheumatic repair. It was a really long operation, and after weaning from bypass, the echo showed that even the great Professor himself could not repair that valve. With apologies, he told us to go on to the restaurant where he'd organized an elaborate farewell dinner, and said he'd join us there. But as everyone left the amphitheater, I noticed the camera feed from the operating room was still live, and I stayed back alone to watch. A few minutes later, Dr Carpentier scrubbed back in, and meticulously reexamined the valve, trying to understand his failure. After considerable time, in total silence, he replaced the valve, and then waited to confirm the patient was safely off bypass.

As I sat there, what struck me was that Dr Carpentier was the exact same surgeon with or without an audience. And banquet or no banquet, he was unwilling to delegate what he considered his responsibility. Seeing his dedication took me back to one of my earliest lessons as a surgical intern: Alain Carpentier was being a doctor.

These are the kinds of lessons you don't learn from books-you learn them from mentors. And it's through them, and through my patients and their families, that I came to realize the honor, joy, and responsibility of being a cardiothoracic surgeon. All of us in this room have been inspired by teachers and mentors along the way. Thanks to them, we're privileged to do what we love. We repay them by making a similar investment in those who follow us into this calling.

In addition to my mentors, the opportunities that you have given me-first to become an AATS member, and then a leader-have profoundly shaped my career. The AATS has been a beacon of excellence for the past 102 years, and it's been my greatest honor to serve each of you as its 99th President.

A century of excellence-that's a long time. But one danger of such longstanding success is complacency. It happens to great companies, it happens to championship sports teams, and it can also happen to elite academic organizations. So, as stewards of the AATS, it's healthy-even necessary-that we always ask ourselves: How do we avoid complacency? How can we keep growing stronger? How can we make an even bigger impact on our patients and the world?

Because progress is never inevitable. Progress is fueled by dissatisfaction, impatience, and vision. It's driven not by the idea that we could do better, but that we must do better. That's why the words you see here-Vision, Leadership, Scholarship - they're not just rhetoric. For the AATS, they're guiding principles; principles that informed every major initiative we developed this year to strengthen our organization and our specialty.

Given their magnitude, many of these initiatives will take several years to fully develop and execute. That's why I'm so thankful to President-elect Dr Vaughn Starnes, Vice President Dr Marc Moon, Secretary Dr David Jones, and Treasurer Dr Shaf Keshavjee for working with me as true partners - and with such clarity of purpose-to articulate and map out a shared, long-term vision. I'm also so grateful to the Council for their decisive leadership this year. I also want to thank Cindy VerColen and the entire AATS staff. We asked so much of you this year, and you really delivered.

One of our first priorities as a leadership team was to examine how the AATS is governed, how we select members and leaders, and how we create-or fail to create-enough opportunities for members to contribute and grow. We even debated our mission, and how best to fulfill it. Frankly, these debates got heated, because looking at yourself is hard, and so is change. Some senior colleagues raised good questions about the scope and pace of such change, and I really appreciated that, because vigorous debate is healthy, and we're stronger for it. Ultimately, with overwhelming support from both leadership and you our members:

- We transformed the AATS Council into a Board of Directors, and expanded the number of Board seats to create more leadership opportunities.

- We shortened terms for key executive leadership roles, to ensure the infusion of new energy and new ideas.

- We set up a new process to give members a direct vote on a Board seat, to amplify your voice in decision-making.

- We refined our branding and communication strategies, to enhance our engagement in this digital age. We implemented an e-voting system to make it easier for you, our members, to be heard.

- And we completely redesigned the annual meeting to engage more members and catalyze a richer exchange of ideas.

This represents real progress; thank you all for making it possible.

In the opening plenary session, Dr Gene Blackstone introduced our new AATS Quality Assessment Program. This novel, interactive platform will transform the way we 


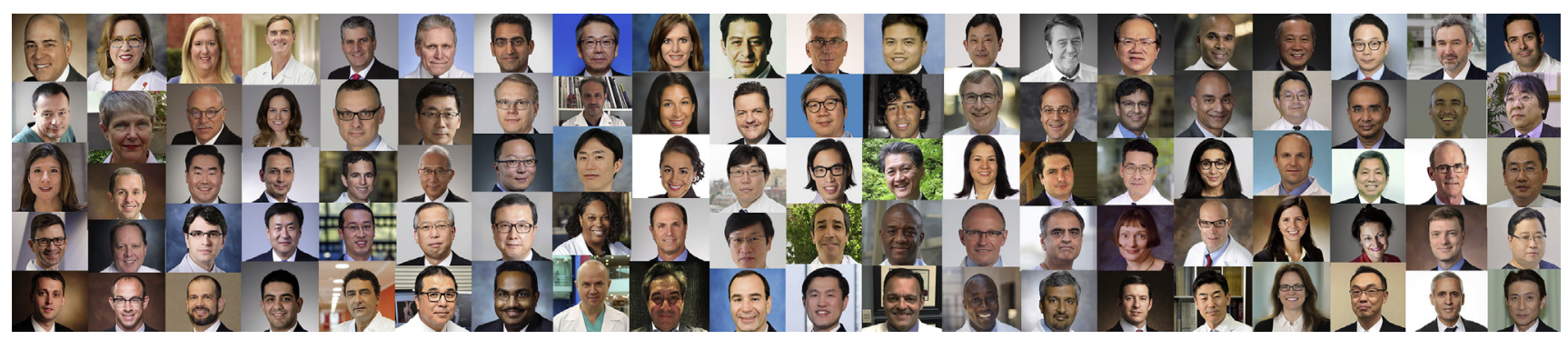

FIGURE 6. The American Association for Thoracic Surgery welcomed 97 new members in 2019-its largest and most diverse class ever.

collect, process, and visualize data—which will greatly benefit our patients. I am hopeful this will grow into a global initiative. Obviously, this new AATS Quality Assessment Program is an ambitious vision, but most worthy endeavors are. Our specialty was founded on audacity, and it's our responsibility to keep challenging the frontiers of possibility.

Finally, I'm extremely proud our new AATS membership initiative. This year, we charged our membership committee to judge candidates not just on their scholarship, but also on how they model all of our core values-Leadership, Education, Research and Innovation, Excellence in Patient Care, and Mentoring. We also intensified our outreach to you for nominations. And thanks to the leadership of Dr Rosemary Kelly and the entire committee, we accelerated the review process. My personal goal was 99 new members for our 99 th annual meeting. We didn't quite get there, but we are welcoming 97 new members todaydoubling the size of the 2018 class, and adding much greater diversity). Our new members reflect not just where we've been as a specialty, but where we're going, and I welcome each of you with gratitude and respect (Figure 6).

Let's keep up this momentum. If you know a worthy candidate, nominate them. And if you've been thinking of applying for membership yourself, make your best case. But remember, joining our ranks isn't a moment of professional arrival, but rather a point of departure, toward new challenges and responsibilities. Membership should inspire an even deeper sense of urgency about challenging conventions, advancing our knowledge, and improving patient outcomes.

So, whether you've been a member for a day or a decade, or still aspire to join us, I ask you: What is your personal vision for cardiothoracic surgery? How can your leadership make a bigger impact on the patients we serve? What does scholarship mean to you, in your daily practice? Vision. Leadership. Scholarship. Easy words to say, yet hard to execute. So, here are 5 actions I suggest we all pursue this year that will help translate these abstractions into reality:

First, learn one aspect of surgery better than your peers, and be generous with your expertise among your partners and colleagues. The best patient outcomes strengthen our specialty.

Second, stay current on the latest guidelines and innovations, and put your patients into clinical trials. Do your part to create the evidence base that shapes the future of cardiothoracic surgery.

Third, I challenge every member here to engage with the AATS Foundation and become a donor. We should all be willing to underwrite the scholarship that advances our mission.

Fourth, get behind our new AATS Quality Assessment Program. Collaborate with us to realize the true potential and power of this novel interactive platform.

Finally, invest in the next generation of cardiothoracic surgeons by proactively mentoring someone this yearit's how we pass on not just our experience, but also our values. And if you're in that next generation, I urge you to actively seek out mentors, and learn everything you can. If you're fortunate, they will teach by example — as mine certainly did — the true meaning of vision, leadership, and scholarship.

Wherever we are in our careers, we should always be asking ourselves: Am I still growing? Am I contributing

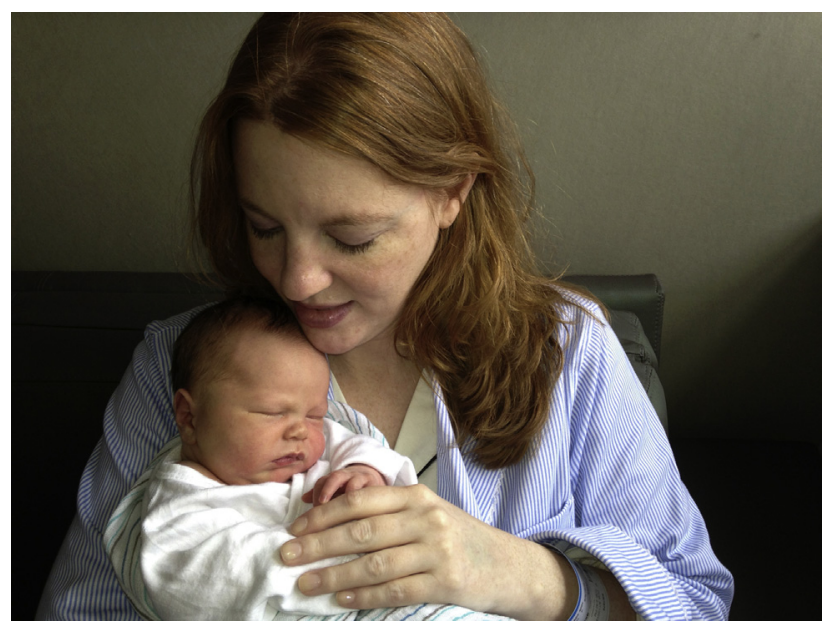

FIGURE 7. Dr Adams' wife, Mary Ann, holds their newborn son, David $\mathrm{Jr}$, in 2013. 


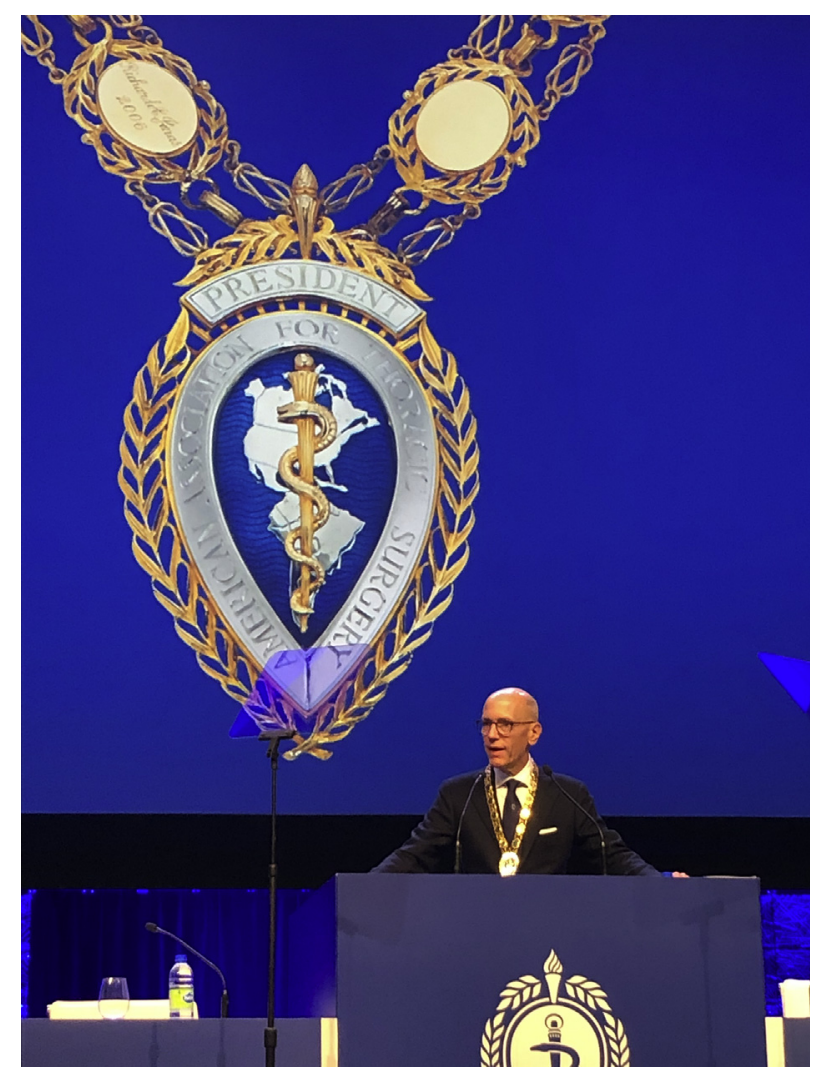

FIGURE 8. The American Association for Thoracic Surgery Presidential Chain reflects the critical role that every AATS member plays in what is an intrinsically collaborative endeavor. "We are all links in the chain," Dr Adams said.

enough? Am I leading by example? Inevitably, time will pass. But what we do with that time, and how we put it to work, that's our choice. So, let's make the most of it-individually, and together.

David Sugarbaker's favorite word was loyalty. He often noted how rare it was, and once told me: "At the end of your life, you've done well if you have about 10 loyal friends, and remember, half of them will share your last name." His message was: no matter what demands your career might make, always cherish your true friends, and always invest in your family. I'm so glad David's wife Linda and daughter Debbie are here with my own family today. And I'm so honored that all of our closest family friends came to Toronto, too.

I also deeply appreciate that so many of my clinical family at Mount Sinai-my partners, colleagues, trainees, and staff-are here, as well. In so many ways, our program has always been a family business, one I feel privileged to lead. My clinical administrator, Teresa Kearns, has sat outside my door for 27 years. Her dedication to patients is legendary, and she's responsible for much of my success. I learned a long time ago to listen to her, only in part because she happens to be my mother-in-law. My brothers, Morgan and Bill, have been 2 of my best friends and biggest supporters my whole life, and I'm so glad they are here today.

The number one person I have to thank today is my wife, Mary Ann. Over the past 20 years, she has taught me the true meaning of love and joy. She remains the quiet leader of our family, and the most influential partner in my life's work. Six years ago, we were blessed by the arrival of our son David $\mathrm{Jr}$ - my greatest teacher of all (Figure 7). My love for him knows no bounds-and that love reinforces my sense of responsibility to my patients. David has brought my career lessons full circle. We must always treat every patient as we would want our own loved ones to be treated.

I want to close with one last story. It's about the presidential chain that I'm wearing today. Last year in San Diego, after receiving the chain, I wore it to the Presidential reception. Later that night, I decided I wasn't going to follow tradition and return it to some safe in Boston for the year. Instead, I would take it back to New York, to share with my family and my team. Well, the next morning at breakfast, I ran into my close friend, Dr Joseph Coselli, our 96th President. Without looking up from his newspaper, he said: "So, I hear you're taking the chain back home? You know David, you're always one step ahead." The truth is, I'm usually not. But I really felt this chain ought to be seen and celebrated, not locked up in a box. Because, symbolically, this chain stands for something very important: In the AATS, every one of us is a critical link-president to president, doctor to doctor, colleague to colleague, friend to friend, generation to generation (Figure 8).

This presidential chain isn't like an Olympic gold medal, or a Wimbledon trophy, or a Green Jacket down in Augusta-all of which are awarded for individual performance. No, this chain is more like the Lombardi Trophy, or the Stanley Cup, or the World Cup-all awards that celebrate the shared accomplishments of a great team. I didn't earn this chain on my own, and I wish I had enough time to call out everyone who rightfully shares this honor, or who helped me along the way. But their names fill this screen behind me. Ultimately, this chain belongs to all of you. Because thoracic surgery-our life's calling - has always been a team endeavor, and always will be. We are all links in this chain.

So, as I prepare to pass it on to our next president tonight, please know how immensely grateful I am to all those who came before us, to all of you, and to the generations who follow. Together-through vision, leadership, and scholarship-may we help our patients and our world become stronger, healthier, and more hopeful every day.

Thank you.

The author would like to recognize the invaluable support of John Pollack and Gideon Sims in the preparation of this presidential address. 